\title{
Between arguments, interests and expertise: the institutional development of the Dutch water boards, 1953-present
}

\author{
Erik Mostert ${ }^{1}$
}

Received: 18 August 2015/ Accepted: 5 February 2016

(C) The Author(s) 2016. This article is published with open access at Springerlink.com

\begin{abstract}
The Dutch water boards perform essential tasks for the Netherlands and generally effectively, yet they have often been called old-fashioned, ineffective and expensive. This paper describes and analyses the discussions on the water boards since 1953 in order to increase insight in the factors that influence institutional change in water management. In this period the water boards have changed a lot: their number has been reduced from 2670 to 24 , they got new tasks, and more groups are now represented and contribute financially. But they have also successfully resisted proposals to abolish them or cancel the reserved seats for specific groups. Change occurred when groups with a vested interest in the water boards, such as agriculture, saw the change as strengthening the boards, and when these groups were relatively weak and could be overruled. In other cases there was continuity. One of the factors influencing the strength of these groups was their influence on public discourse via, for instance, the many advisory bodies with water board experts on them.
\end{abstract}

Keywords The Netherlands - Water boards - Governance - Institutional development · Agriculture

\section{Introduction}

This paper tells a story about institutions for water management and how they develop. Institutions can be defined as "humanly devised constraints that structure human interaction" (North 1990, p. 3). The Dutch water boards provide interesting examples of such institutions. The water boards have changed a lot since the first were established in the

Erik Mostert

e.mostert@tudelft.n

1 Department of Water Management, Delft University of Technology, Stevinweg 1, 2628 CN Delft, The Netherlands 
Middle Ages to improve drainage and flood protection, but they still perform essential tasks for the Netherlands and generally effectively. Nonetheless, they have been called oldfashioned and expensive and their democratic legitimacy has been challenged.

My aim in writing this paper is to increase insight in the factors that influence the development of water management institutions and thereby water management itself. To this end, I will describe and analyse the discussions on the Dutch water boards since 1953, when the last major flood occurred. More specifically, I will address the following questions:

- Which arguments were used by the different parties?

- What was the outcome of the discussions?

- What role did vested interests play?

- What role did advisory bodies play?

There is surprisingly little literature that addresses these questions for the modern period. The main work to be mentioned is the PhD thesis of Herman Havekes (2008), which addresses the more normative question whether there is still a role for independent water boards in the future and answers this question in the affirmative. It contains a wealth of information on the institutional development of the water boards since 1953, but it pays relatively little attention to the issue of vested interests. Van der Ham's (1999) PhD thesis on the National Water Management Agency in the twentieth century also gives a lot of information on the water boards, but mostly for the period until 1970. In addition, several monographs on individual water boards or groups of water boards have been published that cover (part of) the post-1953 period, but these necessarily have a more regional focus and do not cover the national discussions in detail (e.g. Antonisse 1980; Lambooij and Aten 2002; Van den Noort 2009; Van der Ham and Jacobs 2004).

The present paper is based mostly on primary sources: advisory reports, Parliamentary documents such as minutes of sessions (available at www.statengeneraaldigitaal.nl and www.overheid.nl), and contemporary literature. In addition, I have consulted the biographical archive of the Centre for Parliamentary Documentation of Leiden University to obtain background information on the main players (www.parlement.com). The paper starts with a short sketch of the development of the water boards until 1953. In the following sections, I describe the discussions in five consecutive periods, detailing the arguments that were used and the outcome of the discussions. In the final section, I analyse the discussions, focusing on the role of vested interest and advisory bodies.

\section{Developments until 1953}

Although water boards nowadays play an important role in Dutch water management, there was a time without water boards. Originally, dykes, drainage canals and other water management works were constructed and maintained by the individual land owners and users, who were supervised by feudal government bodies (Henderikx 2001; De Vries Azn. 1876; cf. Soens 2009). From the twelfth century onwards, however, specialised water boards with judiciary and regulatory powers were established to supervise maintenance, and from the fifteenth century onwards, these water boards increasingly undertook maintenance themselves, which they financed by means of taxation (e.g. Mostert 2012).

In the nineteenth century important changes took place as a result of the of the introduction of parliamentary democracy and the separation of powers. The water boards lost their judicial powers (Giebels 1992) and direct elections were introduced, but only for the 
land owners. In addition, many new water boards were established for newly reclaimed polders, new infrastructural works, and improving the drainage of complete river basins (Yzerman 1934; Roeffen 1963; Van de Ven 2004).

In 1950, two water boards got a completely new task: sewage treatment (IJff 1995; Boer 1963; Van den Noort 2009). The first sewage treatment plants had been municipal (Van Lohuizen 2006), but from the 1930s onward a regional approach was advocated as this would be more effective than isolated local activities, ensure a technical-rational solution, and facilitate cost sharing (Donner 1935; Studie-Commissie 1935). The water boards were originally not very enthusiastic about this new task because of the costs and because the polluters would have to be represented on the board if they were to contribute to the costs (Donker 1996; Donner 1935). Besides, most water boards were still far too small for this complex task.

On the eve of the 1953 flood disaster, there were nearly 2670 water boards (Ministerie van Verkeer en Waterstaat 1952; Mansholt 1941; see Table 1). These included:

- a limited number of regional water boards, responsible for flood protection and major drainage works and for supervising the smaller polder boards in their area;

- the supervised polder boards, responsible for the detailed drainage of their own area;

- water boards that were neither supervising nor supervised by other water boards, responsible for flood protection, drainage or both;

- twenty water boards in the province of Zeeland responsible for the dykes of so-called "calamitous polders": polders that had a too small economic basis for maintaining their own dykes (Antonisse 1980);

- water boards responsible for drainage works serving several polders, such as a pumping station or large drainage canals;

- two water boards responsible for sewage treatment; and

- circa 140 water boards established exclusively for financing and maintaining roads or bridges

The board members were usually elected representatives of the land owners in their area. In a few water boards owners of buildings were represented as well. Their representatives were appointed by the municipal councils in the area, as were the representatives of domestic polluters in the two water boards responsible for sewage treatment. Representatives of industrial polluters in these two water boards were appointed by the Chambers of Commerce in their area.

The groups represented in the boards also financed the water boards, through the water board tax. The governance system was based on the principle of "unity of pay, say and interest", meaning that those groups with an interest in the task of the water board should contribute financially and should also be represented in proportion to their interest. The

Table 1 Number of water boards between 1953 and 2015

\begin{tabular}{lll}
\hline Year & Number & Sources/notes \\
\hline 1953 & ca 2670 & Ministerie van Verkeer en Waterstaat (1952) \\
1962 & ca 2000 & Werkgroep Waterschapsfinanciën (1967) \\
1974 & ca 800 & Studiecommissie Waterschappen (1974) \\
1988 & 153 & Anonymous (1988) \\
1999 & 63 & Commissie Togtema (1999) \\
Since 1-1-2014 & 24 & Including water board Blija Buitendijks (100 ha) \\
\hline
\end{tabular}


details of the governance system were regulated by the province, who could also establish new and merge existing water boards, subject to approval by national government. National legislation was limited and focused on giving the water boards the competence to make and enforce rules and take action during emergencies (e.g. Schilthuis 1960; Kooiman 1928-1932).

The small size of most water boards posed some problems. They often had an insufficient tax base for hiring specialized technical staff and even for maintaining their water management infrastructure. Maintenance of the sea dykes was often the responsibility of the polders located on the sea front, and in many cases polders located more inland that were also protected by the dykes did not contribute anything. In these cases provincial and later national government were often asked for tax exemptions or subsidies, and in a few cases the province or the State took over responsibility for the dykes. In other cases the inland polders were made to contribute, polders were merged, or a new regional water board was established to take over responsibility for the sea dykes and spread the financial burden over all beneficiaries (Maas 1963; Mostert 2012; Pauwels 1937; Schorer 1897; Van der Flier 1946).

Initiatives to merge water boards and spread the costs more evenly often met with resistance. It was argued that this would affect property rights since land that was taxed lightly was worth more and had often been bought more dearly than land that was taxed more heavily. Equalizing taxes would therefore result in unjustified losses for some and unjustified gains for others (e.g. Antonisse 1980; Anonymous 1839, pp. 106-112; De Vries Azn. 1876, pp. 192-193). Moreover, farmers were afraid that upscaling would result in higher tariffs since the water boards would rely less on in-kind contributions and more on paid staff (Antonisse 1980). Furthermore, it was feared that water management would become more bureaucratic and involvement of the farmers would decrease. And finally, some water board members coveted the status their position brought them or identified themselves with their position and interpreted abolishment of "their" board as criticism (e.g. Hordijk 1983; Polak 1954; Ormel 1954; IJff 1993; Lambooij and Aten 2002).

\section{The 1953 flood and its direct aftermath}

And then came the 1953 flood disaster. On the night of 31 January to 1 February, a heavy storm swept across the North Sea, resulting in record water levels. In the South-West of the Netherlands, the dykes breached at some 150 locations and 136,000 ha of land was inundated. Casualties numbered 1836 (Slager 2003; Gerritsen 2005).

The top priority after the disaster was repairing the dykes (see Van der Ham 1999). To legalize initiatives that had already started, the Cabinet drafted a bill concerning emergency measures for dyke repair. The State would take charge of the repairs and also fund them, but only the restoration to the former state, not any improvements. Moreover, the State would take over supervision of the water boards from the provinces. According to the explanatory note, neither the water boards nor the provinces had the technical staff to coordinate the repairs, and the water boards also lacked financial means. On top of this, the disaster was seen as a national issue, and therefore it would only be fair if the State covered the costs (Kamerstukken II 1952/1953, 2926, nr. 3).

The bill was adopted by Parliament, but not without discussion. Some MPs argued that a centralized approach would not be inherently better than a more decentralized one because many of the dykes for which the State was responsible had failed as well (e.g. Handelingen Tweede Kamer 1952-1953, p. 3462). Consequently, the State should take over the repairs 
and supervision only in exceptional cases (e.g. Kamerstukken II 1952/53, 2926, nr. 4). In this context, it may be interesting to note that several MPs were or had been water board officials, especially MPs of the confessional (Roman-Catholic and Protestant) parties and the Liberal Party. Moreover, water boards fitted very well in the political theories of the confessional parties at the time, which gave a large role to societal organizations other than the State (Van Doorn 1989; Josephus Jitta 1936). Nonetheless, there were also MPs who questioned the Government's statement that as little as possible should be changed in the distribution of responsibilities. As one senator put it, the old Dutch principle "who's affected by water should defend himself against the water" should be re-interpreted as requiring national flood protection since the whole population had been affected by the flood disaster (Louwes, in Nieuwe Rotterdamsche Courant of 4 March 1953; cf. Commissie Gemeenten-Waterschappen 1955).

At the provincial level, the flood disaster did not immediately lead to large changes, but it did speed up developments. In the province of Zuid-Holland, so-called "dyke rings" were already being established: water boards for managing the flood defences of complete islands. Moreover, the owners of buildings were made to contribute financially. The tariffs in urbanized areas were kept low to prevent that the owners of buildings would contribute more than half of the total costs and therefore would get the majority on the board. This was considered to conflict with the agricultural interest in the water boards. Representatives of the owners of buildings were appointed by the executive boards of the municipalities as direct elections would be expensive and the interest of the of individual owners would be limited (Ormel 1954; Polak 1954).

In the province of Zeeland less had happened before 1953, but between 1953 and 1965 water boards for complete islands were established, which became responsible for both flood protection and drainage (Antonisse 1980). In North-Brabant, the third province hit hard by the flood disaster, the water boards themselves supported the idea of separate water boards for the main flood defences, to which all interested in flood defence should contribute. In 1953 such a water board was established for the western part of the province: Water board Brabantse Bandijk. Originally, the municipalities, and therefore indirectly all inhabitants, whether they owned real estate or not, contributed financially, but in 1963 the High Court decided that these contributions were illegal because municipalities could only be forced to make expenses against their will by an act of Parliament (Van den Noort 2009).

\section{5-1967: financial problems}

Despite the ongoing concentration of water boards and financial contributions by the owners of buildings, the financial situation of the water boards remained problematic and in some cases even deteriorated. Land rents were regulated and kept relatively low, which limited the financial possibilities of the land owners (e.g. Handelingen Eerste Kamer 1952-1953, p. 3289), and buildings were often undertaxed (see supra). Moreover, many water boards were responsible for roads that needed improvement to accommodate the increasing over-land travel. And last but not least, the costs for flood protection rose.

To improve flood protection, the Delta works were developed. These consisted of a number of new closure dams in the south-western delta and strengthening of the existing coastal defences (Deltacommissie 1961). As stipulated in the Delta Act of 1958, the closure dams were built, managed and financed by the State. The State would, however, receive financial contributions from the water boards located inland from the closure dams 
that as a result would not have to strengthen their dykes. Dyke strengthening on other parts of the coast would be financed by the responsible authorities - often water boards - but the State would contribute financially. According to the explanatory note, these arrangements were based on the benefit principle and the financial capacity principle (Kamerstukken II 1955/56, 4167, nr. 3, pp. 23-24).

Since it was hard to quantify the interests and find an objective standard for financial capacity, and to prevent delays, details would be regulated in a separate act. This act was proposed to Parliament in April 1963 (Kamerstukken II 1962/63, 7173, nr. 2). The subsidies for dyke strengthening would be $75 \%$, and water boards benefitting from a closure dam would have to contribute $25 \%$ of the costs saved; subsidies would be higher and contributions lower if otherwise the costs for the water board concerned would exceed a certain percentage of the rental value of the real estate in its area (Kamerstukken II 1962/63, 7173, nr. 3). Both Parliament and the water boards considered this insufficient. They demanded subsidies of $95 \%$ and contributions of $5 \%$, emphasizing the national interest in flood protection and the fact that many local interests were beyond the scope of the water board taxes (Kamerstukken II 1963/64, 7173, nr. 5).

Meanwhile, the financial situation of the water boards was not improving. In 1960, the water board tax that the land owners had to pay was often between 30 and $50 \%$ of the rental value and in a few cases even exceeded $100 \%$ (Werkgroep Waterschapsfinanciën 1967, annex II). Already in 1953, the Minister of Public Works had established a committee to study the issue, but they could not reach agreement (Van der Ham 1999, p. 270). In 1963, the national Association of water boards proposed that the water boards should receive $30 \%$ of their budget from the State because the activities of the water boards benefitted far more people than those paying the water board taxes. This would not have to entail more influence of the State because the water boards were already supervised by the provinces and they were thrifty anyway (Werkgroep Waterschapsfinanciën 1967, Annex I).

In reaction to this proposal, an inter-ministerial commission was set up to advise on the issue. The commission fundamentally disagreed with the Association of water boards, arguing that it is quite common for government bodies to benefit others and that this did not constitute a ground for general budget support. Instead, it proposed that the water boards should lose tasks that did not benefit primarily the real estate owners and polluters, more specifically road maintenance, recreational facilities, and the coastal flood defences. Concerning the latter, the commission argued that the different coastal defences function as one system and should therefore be managed as such, by the State (Werkgroep Waterschapsfinanciën 1967).

Naturally, the water boards were not very happy with this advice (Havekes 2008, p. 27). More positive for the water boards was the Cabinet's new position in the following year concerning the subsidies and contribution for the Delta works. Cabinet maintained its position that the protected lands would benefit most and should therefore contribute financially, but it recognized that few water boards were capable to do so. Consequently, and to simplify administration, the financial contributions were cancelled and subsidies were raised to $100 \%$ (Kamerstukken II 1968/69, 7173, nr. 6).

In addition, some ad-hoc measures were taken to improve the financial situation of the water boards. From 1962 onwards, water boards could get a subsidy of 25 to $40 \%$ or more for new sewage treatment plants (Jansen 1995). Moreover, new water management works that were part of land reallotment projects and benefited agriculture were subsidized. Furthermore, subsidies for maintaining flood defences were introduced: in 1969 for the flood defences along the main rivers and Lake Ijssel and behind the closure dams, and in 1971 for the coastal flood defences (Studiecommissie Waterschappen 1974, pp. 76-77). 


\section{8-1991: functional government or not?}

Since the financial problems of the water boards depended on the tasks they had to perform and the groups and objects they could tax, the discussions soon turned to the structure and function of the water boards. A key issue in this period was whether the water boards should be kept as a form of "functional government." Functional government refers to all government bodies with a limited task, as opposed to "general government" with a broad task, such as municipalities and provinces. Especially in the 1970s, functional government was often criticized because it would complicate government, in particular integrated planning and management; because partial interests could prevail over the general or public interest; and because it would be less democratic than general government, for which general elections are held (Van de Berg 1982).

The first commission that had a fundamental look at the water boards was established in 1968 and published its advice in 1974 (Studiecommissie Waterschappen 1974). It concluded that also in the future regional and local water management should be the task of water boards because they give influence to the groups that have a specific interest in their tasks and also contribute financially. In addition, their area can be based on water management units. The tasks of the water boards should include flood defence, as well as water quality control and sewage treatment. Groups to be represented on the boards were the owners and users of land, the owners of houses, the users of commercial premises, and the polluters; the users of houses would be represented by the owners as their interests were supposed to coincide. The commission recognized that the work of the water boards increasingly served other interests as well, such as nature protection, recreation and industrialization, but it considered this relatively unimportant. Moreover, supervision by the provinces could help ensure that these interests were not overlooked. Finally, the commission advised to make a national water board act.

Two and a half years later, the Minister of Public Works reacted to this advice in the form of a discussion note to Parliament (Kamerstukken II 1976/77, 14480, nr. 2). While generally supporting the conclusions, the Minister did not consider sewage treatment to be an essential task of the water boards, first, because sewage treatment is linked more to waste streams than to surface water, and second, because the interest of the polluters in sewage treatment is very different from the interests of the other groups in water control and flood protection. Moreover, to safeguard the other interests served by water boards, the provinces should be involved in policy making. Furthermore, the inhabitants of the water board should be represented in the board as well, preferably by means of direct elections. All groups represented would have to contribute financially, but the number of seats should be proportional to their interest, not to their financial contribution. In particular groups depending for their livelihood on water management—agriculture-would have to be well represented.

The discussion note was discussed in Parliament nearly a year later, after parliamentary elections and after a new coalition government had been formed (Handelingen Tweede Kamer OCV/UCV 1977/78, 24 April 1978, pp. 409-432). The representative of the new Christian Democratic Party, who was also a secretary and treasurer of a water board, was supportive of the note, as was the representative of the Liberal Party, who had an agricultural background, like the new Minister of Public Works. The representatives of the Social Democrats and of the progressive liberal party D66 were quite critical. The Social Democratic MP wanted to give half of the seats on the boards to representatives of the "general interests", directly elected by the inhabitants, and the MP from D66 argued for 
general elections for all seats because the activities of the water boards benefit everybody. ${ }^{1}$ The latter proposed a motion to that extent, but it was not adopted by Parliament.

More-or-less simultaneously, the Commission Merkx prepared its advice. This commission, named after its chair person, had been established on 1 December 1976 by the Association of water boards and included not only water board representatives, but also municipal and provincial representatives and MPs. Its task was to advise on the composition of the future water boards; the election or appointment of their members and their remuneration; and the possibilities for improving public participation (Commissie waterschapsbestuur 1979). The commission based its advice on an analysis of the different interests involved, distinguishing between "task interests" in the field of water management that a water board has to serve specifically, and "related interests" that are affected by the water board's activities and that the water board has to consider, such as environmental protection and landscape. The Commission further distinguished between "general task interests" that serve everybody living or staying in the water board, and "specific task interests" that serve specific groups. The Commission then moved on to discuss the main tasks; the specific groups that these tasks served, if any; and the number of seats these groups and the inhabitants as representing the general task interests should get on the board.

Two members the Commission Merkx, both Social Democrats, did not agree with the conclusions, and consequently a minority opinion was attached to the Commission's advice. According to these members, general elections should be held for the water board because the water board's activities are becoming so entwined with government tasks generally that any attempt to compose the board on a functional basis would be arbitrary and open to criticism. General elections would also give more real influence to domestic polluters, house owners and small companies, who at the time were represented only indirectly through the municipalities.

At the provincial level, policies differed, and it was the provinces who regulated the water boards and could establish or abolish them, subject to approval by national government. In 1969, the Act on surface water pollution had been adopted, giving the provinces responsibility for water quality management, including sewage treatment. Most delegated this task to existing water boards or established new "purification boards" for this purpose. Three provinces, however, kept responsibility for water quality management (Groningen, Friesland and Utrecht: IJff 1995). In the 1970s, the Province of Groningen even wanted to transfer all water management tasks to the province, except for small-scale drainage works (Kienhuis 1993).

Following the Parliamentary discussions on the discussion note to Parliament (see supra), a national Water board act was prepared, in collaboration with the Association of water boards and the provinces. The provinces wanted to keep their role in supervising and regulating the water boards, but the water boards wanted more regulated in the act itself, most likely so as not to depend on provincial politics (cf. Handelingen Tweede Kamer 1982-1983, p. 1842). In Parliament, the Social Democrats were critical. They argued for the possibility of general elections, raised the issue why for instance shipping and fishing interests were not represented in the water boards, and stated that if the functional character of the water boards was kept, this would limit the number and type of tasks they could

${ }^{1}$ Cf. the minority opinion in Commissie Waterschapsbestel (1967), a report of the Wiardi Beckman Stichting, the scientific institute of the Social Democrats. The Social Democrats were usually quite critical of the water boards, but the working group preparing the report included several persons active in the water boards. This can help explain why the majority did not want to change interest representation on the boards. 
perform (e.g. Kamerstukken II 1988/89, 19995, nr. 12). The majority, however, was supportive of the Government proposal and suggested to include a provision in the act stating that, as a rule, regional water management should be the task of water boards. This the Minister did.

\section{2-2008: continued discussions}

The Water board act was adopted in 1991 and entered into force on 1 January 1992. It brought a number of changes. Most importantly, it introduced a new category in the board, the inhabitants, who would also have to contribute financially. The other categories were the owners of land, tenants of land, the owners of buildings, and the users of buildings for commercial purposes. The provinces would decide how many seats each category would get.

What the Water board act did not bring was an end to the discussions. A first issue was the elections for the representatives of the inhabitants and the owners of buildings. The Water board act had introduced direct elections for these categories as these were supposed to be more democratic than indirect elections by the municipal councils. Inhabitants and owners could, however, only vote on individual candidates, not on parties with their own programme. This was assumed to follow from the functional character of the water boards. According to the explanatory note to the act, the purpose of the elections was not to determine the relative strength of different political groups, as is the case with municipal, provincial and national elections, since the relative strength of the different groups- the different categories-was fixed by the province. Instead, the purpose was to select individuals to fill the available positions (Kamerstukken II 1987/88, 19995, nr. 3, pp. 31-32).

In practice, the electoral system had some questionable effects. Most inhabitants and owners of buildings did not know what a water board does and they certainly did not know the individual candidates. As a result, turnout at the elections was usually 20-25\% only, despite publicity campaigns and despite the possibility to vote by mail or, later, online. Moreover, groups that could lobby well, such as agriculture, got a disproportionate number of votes (Hoeben 2011). Candidates that ended up on the ballot paper at the top nearly always got elected because that is the place for the party leaders in general elections (Katsburg 1996). And finally, many votes were lost as votes cast on candidates that did not get elected or that already got enough votes did not have any effect on the outcome.

Other issues discussed in this period included the costs of the water boards elections and of the taxing system, the complexity of Dutch water governance, and the issue whether the water boards had become mere implementing agencies for which separate elections would not be necessary (a "public works department of the province": Provincie Noord-Holland 2004, p. 9). Those defending the position of the water boards as independent authorities argued that potential costs savings were small and that the quality of water governance is more important than narrowly defined efficiency (e.g. Toonen et al. 2006). They moreover argued that the water boards still take important decisions and have their own taxes, and that therefore an accountability mechanism involving the tax payers is needed. As to the complexity of Dutch water governance, it was argued that the number of government bodies would not be reduced significantly if the water boards were brought under the provinces or merged with the State Water Management Agency (e.g. Havekes 2008, p. 140). Other arguments in favour of keeping the water boards as separate authorities were that water boards are based on water management units, unlike for instance the provinces. Furthermore, they have a lot of expertise and they are functioning well, so why waste time 
and energy on reorganization (e.g. Meijerink 2010)? In addition, they were often presented as the oldest democratic institutions in the Netherlands (e.g. Lazaroms and Poos 2004; Huisman 2002).

The theory of functional government continued to be used to support separate water boards. This was for instance the approach of the "Think Tank", an advisory body set up by the Association of water boards to study the future of the water boards (Denktank 1996). The Think Tank also embraced the idea of all-in water boards, responsible for both water quantity and water quality, as a means to implement integrated water management (cf. Mostert 2006). This idea had met with some resistance, the main argument being that the optimal scale would often be larger for water quality than for water quantity and that all-in water boards would therefore result in a too large scale for water quantity and unnecessarily reduce the involvement of the individual land owners (e.g. IJff 1993, 1995). Since 2005 all water boards are all-in.

A new argument or rather emphasis in this period was that water management is an essential precondition for life in the Netherlands that can be entrusted best to governance bodies that deal exclusively with this task. This would make balancing between water interests and other interests, represented by general government bodies, a more conscious process (Toonen and Glim 2000). A counter-argument was that firefighting, education, and health care are equally important and there are no independent boards for these tasks (e.g. Smit 2004, Raad voor de financiële verhoudingen 2005). In addition, the water boards were presented as a form of common pool resources management as described by Ostrom (1990; Raadschelders and Toonen 1993). To explain the low turnout at the elections, a new term was introduced: "protective democracy." The purpose of protective democracy would not to be to help determine policy, but to control the members of the executive and prevent the abuse of power. In this perspective, low turnout at elections is positive as it would mean there are no big problems (Boogers and Tops 2000).

In 1996, the Think Tank (see supra) had concluded that the financing system for the water boards was quite complex and not very transparent. The Association of water boards accepted this conclusion, and in 1997 it set up the Commission Togtema to study whether it would be possible to develop a simpler financing structure. In its interim report of 1998, this commission stated that most of water management has a public good character, benefitting everybody more-or-less equally, and that therefore everybody should contribute financially. In its final advice, however, the commission abandoned these potentially revolutionary ideas and adopted the terminology introduced by the Commission Merkx in 1979 (see supra). Inhabitants as representatives of the "general task interest" would have to pay maximally $50 \%$ of the costs, and the remainder would be shared by the owners of buildings, of agricultural land, and of nature areas. The costs of sewage treatment would be paid by the polluters separately through a separate treatment charge (Commissie Togtema 1999).

On top of this, the Ministry of Finances set up an inter-ministerial working group in October 2002 to advise on the question how best to finance integrated water resources management. Within the working group there were "sometimes intensive discussions", which often were "not so much about financing, but about the governance and organization of water management" (Werkgroep IBO Bekostiging Waterbeheer 2004, foreword). The working group came up with four different alternatives, ranging from small modifications to the water board tasks being taken over by the State Water Management Agency. In its reaction to the report, Cabinet opted for small modifications and keeping the water boards. The reason given was derived directly from Toonen and Glim (2000): "having separate bodies representing the interest of water management makes balancing water management interests and other interests a more conscious process" (Tweede Kamer 2003-2004, 19428, nr. 1). 
Following the Cabinet reaction, a revision of the Water board act was prepared. The Cabinet proposed to change the categories of interested parties, following a proposal of a working group of the Association of water boards, the Working Group Van der Vliet. The new categories would be inhabitants, owners of agricultural land, owners of nature areas, and industry. The owners of buildings would have to pay taxes as well, but they would be represented by the inhabitants and industry. Only the representatives of the inhabitants would be elected; representatives of the other three categories would be appointed by representative organizations.

For the elections party lists were proposed. In Parliament, the Christian Democrats, were against this as this was supposed to conflict with the functional, a-political character of the water boards (Kamerstukken II 2005/06, 30601, nr. 5, nr. 24). Their water specialist at the time had been a staff member of the national agricultural organization LTO, and for agriculture the existing electoral system worked quite well. Initially, the Minister had proposed to exclude political parties to take part under their own name, to make clear that water board elections are not general political elections, but following the advice of the Council of State, this idea was dropped (Kamerstukken II 2005/06, 30601, nr. 4). This too was opposed by the Christian Democrats, and for the same reason: it would conflict with the a-political character of the water boards. The majority in Parliament, however, agreed with the Minister, so the proposal was not changed on this point.

In the Senate, there was opposition from an unexpected corner: the Christian Democratic senator Wagemakers. He argued that with the advent of the policy of integrated water resources management and the proposed introduction of party lists, the water boards were no longer a form of functional government and had become general government bodies, for which the Dutch Constitution and the 1st Protocol to the European Convention on the Human Rights required general elections. Wagemakers was not against representation of specific interest groups as such, but he considered appointment by organizations selected by government to be very undemocratic (Kamerstukken I 2005/06, B, Handelingen Eerste Kamer 2006/07, pp. 21-65).

Despite this opposition, the proposal was adopted on 15 May 2007, and in November 2008 the first elections under the revised Water board act were held. Several political parties participated, as well as water board specific parties. Average turnout was $22.68 \%$, not higher than for previous elections. Only in the Province of Zeeland, which had been hit hardest in 1953, did turnout exceed $30 \%$ (Glim et al. 2009).

\section{9-present: budget cuts and politics}

Following the banking crisis of 2008, the Cabinet announced in Spring 2009 that it wanted to reduce the budget for water management by $€ 100 \mathrm{mln}$. The Association of water boards used this announcement to come up with a proposal that many saw as a "flight forward" (Meijerink 2010). It proposed to take over part of the costs for strengthening the main flood defences, which at the time were born fully by the State. Moreover, it proposed to take over responsibility for the sewers from the municipalities. This would result in better coordination with sewage treatment and in large efficiency gains that could be used for financing the main flood defences (letter of 4 November 2009 to the Deputy-Minister of Infrastructure and the Environment: the "Storm brief").

The Association of municipalities wanted to keep responsibility for the sewers and emphasized the importance of coordination between sewer maintenance and maintenance of the municipal roads. The provinces came with a counter-proposal to turn the water boards into 
provincial agencies. This would result in a cost reduction of $€ 300 \mathrm{mln}$ to $€ 400 \mathrm{mln}$ per year because of lower administrative costs, less overhead, and less double work. Cost reductions in urban water management would be even $€ 550 \mathrm{mln}$ per year, all because of efficiency gains. In reaction, the Association of water boards argued that administrative costs would be reduced by $€ 23 \mathrm{mln} / \mathrm{year}$ only. They contracted the Centre for Research on the Economy of Decentralized Governments of Groningen University, which came up with a figure of $€ 80$ million/year and emphasized the costs of reorganization (Allers and Hoeben 2010).

In the end, national politics would decide. In the political programmes for the penultimate national elections of June 2010, most parties were in favour of abolishing or at least reconsidering the water boards. The coalition agreement of 30 September 2010, however, stated that indirect election for the water boards would be introduced, implying that the water boards would be kept. The financial annex to the agreement included the budget cuts proposed by the Association of Water Boards, but the water boards did not get responsibility for the sewers.

The present Cabinet Rutte II, sworn in on 5 November 2012, initially changed the policy concerning the water boards. Although this time the political programmes of the coalition partners had not mentioned that the water boards should be abolished, ${ }^{2}$ the coalition agreement stated that the number of water boards should be reduced to 10 or 12 and that in the long run they should merge with the five "land parts" that would replace the current 12 provinces. The elections for the water boards would remain direct, and they were postponed to 18 March 2015, to coincide with the provincial elections and boost turnout. This did in fact happen. Turnout this time was $43.7 \%$.

The latest development, apart from the elections, was the publication, in March 2014, of the OECD report "Water governance in the Netherlands: Fit for the future" (OECD 2014). This report had been commissioned by the Ministry of Infrastructure and the Environment and the Association of water boards to get independent international advice on whether Dutch water management is prepared for the future and whether things should be organised differently. The main conclusion was that the Netherlands is a "global reference for water management" (p. 20). The water board model was presented as justified for flooding, but less adequate for sewage treatment because of the different principles on which financing is based and differences in the optimal scale of the tasks (p. 43 and others, Havekes and Hofstra 2014, p. 13). Moreover, the water boards were mentioned as "long-standing facilitator(s) of stakeholder engagement" (p. 261). However, without pointing specifically to the water boards, the report also mentioned that the "corporatist system" of interest representation in Dutch water management has led to an overrepresentation of some interests (p. 278). In her official reaction on the report to Parliament, the Minister took on board many of the suggestions given, but also concluded that the report does not give any reason for reconsidering the organisational setup of Dutch water management (Kamerstukken II, 28 966, nr 27). Parliament seems to have taken over this conclusion, at least it did not question it (Kamerstukken II, 27 625, nr 326).

Currently, there are 24 water boards that together cover the whole country. With the exception of one tiny water board of 100 ha in the North, they are all responsible for both water quantity and water quality. This includes water level control in the polders, the

\footnotetext{
2 The draft political programme of the Social Democrats had mentioned on p. 63 that "the water boards will become implementing agencies under the provinces." At the congress of the Social Democrats of 30 June 2012, however, this passage was voted down. To explain this, it is important to note that by 2012, the Social Democrats had become the third largest party in the water boards and five of the 25 chair persons of water boards were Social Democrats (Theunissen 2012, pp. 8-9).
} 
maintenance of most canals, lakes and rivers, the upkeep of most flood defences, water quality control, and sewage treatment, at a total cost of less than $3 \mathrm{bln}$. Euro/year, or a little under $0.5 \%$ of gross national income (see Table 2).

\section{Discussion}

This paper has described the discussions on the water boards since 1953. The water boards had been set up originally to make the land more productive for agriculture and from the mid-nineteenth century onwards, they were financed and run completely by the land owners, mostly farmers. By the mid-twentieth century, this system did not function well anymore. Agriculture had become a too narrow economic basis and increasingly other interests were made to contribute. The water boards had also come to serve more interests and had gotten new tasks. Many were merged to improve their financial and technical capacity and implement the new policy of integrated water resources management. As a result, their number has decreased from circa 2670 in 1953 to 24 now and their agricultural character has become less pronounced.

When starting work on this paper, I intended to focus on the arguments used in the discussions. My assumption was that, even though arguments may be used strategically to legitimize preferred alternatives, they still show what counts as a valid argument and therefore can be taken to reflect prevalent values (cf. Mostert 2015). During the research this proved to be a too narrow approach. To understand the discussions, I had to pay attention to the interests the parties represented. This helped to explain why some arguments were used and others not and why some old theories are still popular today.

The main theory supporting the water boards was and is the theory of functional government. According to this theory, water boards have a limited task-water management - that serve a number of interests in particular, who should therefore be represented

Table 2 Basic data water boards

\begin{tabular}{|c|c|}
\hline Financial data, in mln Euro ${ }^{a}$ & Composition of the boards ${ }^{b}$ \\
\hline Water board taxes: $2575(100 \%)$ & Total number of seats: $615(100 \%)$ \\
\hline Water system charge $1279(50 \%)$ & Inhabitants: 445 (72.4 \%) \\
\hline Treatment charge $1241(48 \%)$ & Owners of agricultural land: $76(12.4 \%)$ \\
\hline Pollution charge $9(0.3 \%)$ & Owners of nature areas: $28(4.6 \%)$ \\
\hline Roads charge $35(1.4 \%)$ & $\begin{array}{l}\text { Owners and users of commercial buildings: } 66 \\
(10.7 \%)\end{array}$ \\
\hline \multicolumn{2}{|l|}{ Not task specific $11(0.4 \%)$} \\
\hline \multicolumn{2}{|l|}{ According to category } \\
\hline \multicolumn{2}{|l|}{ Inhabitants $^{\mathrm{c}} 1949(75.7 \%)$} \\
\hline \multicolumn{2}{|c|}{ Owners of agricultural land $154(6.0 \%)$} \\
\hline \multicolumn{2}{|l|}{ Owners of nature areas $3(0.1 \%)$} \\
\hline \multicolumn{2}{|c|}{$\begin{array}{l}\text { Owners and users of commercial buildings } 467 \\
(18.1 \%)\end{array}$} \\
\hline \multicolumn{2}{|l|}{ Other income: 257 (2013) } \\
\hline
\end{tabular}


in the water board and contribute financially. However, sewage treatment does not fit in well in this theory since the interests are very different and financing has a different basis. Moreover, one may wonder whether the water boards still serve some interests in particular or whether they serve everybody's interests and should therefore be composed on the basis of general elections. In practice, the water board elections increasingly resemble general elections and nowadays nearly three-quarter of the seats are for the category inhabitants. These inhabitant cannot be assumed to have all the same "functional interest", but instead they have different views on their interests and can vote for the party that represents their views best, just like they can in general elections.

Water boards have been defended on other grounds than the theory of functional government as well. Independent water boards would ensure that water-related issues are not overlooked, they have their own taxes to finance water management, which makes them less dependent on (national) politics, and unlike for instance provinces, they are based on water management units. Yet, this does not require that $28 \%$ of the seats are reserved for specific interest groups. Alternatives one could think of are general elections and turning the water boards into implementing agencies under the provinces in combination with earmarked water taxes, although this last option would reduce independence.

So why is the theory of functional government still popular and why are reserved seats still defended? Part of the answer may be the role of agriculture. Nationally, agriculture contributes $6.0 \%$ of the water board taxes, but $12.4 \%$ of the seats are reserved for them (Table 2). In practice, agriculture even occupies 17 to $38 \%$ of the seats because of its presence in the other categories (Hoeben 2011, Fig. 7). It is clear that agriculture would not gain much if the reserved seats were abolished or the water boards were brought under the provinces.

Agriculture is just one of the groups with a vested interest in the water boards, but it is the biggest. Other groups are industry and nature. A different type of vested interest do the board members have, who have invested time and effort in the water board and may have come to identify themselves with the institution. And a very concrete vested interest is the financial interest of water boards with relatively low costs to stay independent or merge only with other low-cost water boards.

Vested interests do not preclude institutional change. First, change that is seen as strengthening an institution will be welcomed or may even be initiated by those with a vested interest in the institution. And secondly, when vested interests are relatively weak, they can be overruled. This happened for instance in the 1950s and 1960s with small water boards that opposed mergers. At the time the most prominent spokepersons for the water boards were working for large water boards or the province, and they were more interested in strengthening the water boards than in keeping very small water boards with little financial and management capacity. Moreover, the 1953 flood disaster was still fresh on everybody's mind. The current situation is very different. The water boards are now all large and professional and there is no recent disaster that could be linked to the organisation of the water boards (cf. Boin et al. 2009). In addition, contrary to what some feared, the introduction of political parties in 2008 may actually have strengthened the position of the water boards as it resulted in internal lobbies for the boards in political parties that traditionally were quite critical of the water boards (cf. footnote 2).

One of the factors determining the relative strength of vested interests is their ability to influence public discourse, for instance via advisory bodies. As this paper shows, many advisory bodies were set up to study and advise on the future of the water boards. Several of these were set up by the Association of water boards, and we may therefore expect that their members were not only experts on, but also sympathetic towards the water boards. Others were set up by the Minister of Public Works or the Cabinet. But even when 
expertise was the sole criterion for membership, vested interests may have played a role. Expertise is often the result of involvement in practice, and with involvement come personal ties and the development of (psychological or other) stakes. It may therefore come as no surprise that advisory reports have usually been supportive of independent water boards and often proposed non-fundamental changes only. But is may also come as no surprise that these reports have not always convinced more critical and perhaps less knowledgeable outsiders.

In conclusion, what we end up with is in fact an embryonic theory on continuity and change, one that sees continuity and change as the result of competing forces: groups interested in the status quo and groups favouring specific changes (cf. Pierson and Skocpol 2002). The factors determining the relative strength of these groups include the strength of the arguments used; the ability to influence the opinion of decision-makers through for instance advisory bodies; disasters, which may also change opinions; political connections; and the strategies employed; as well as the broader socio-political and cultural context (cf. Mostert 2012). It is unlikely that there will ever be a theory that is both general enough and specific enough to explain all examples of continuity and change in all contexts. But more historical case studies can result in a richer picture of how different factors can combine at specific times and places to produce continuity or change.

Open Access This article is distributed under the terms of the Creative Commons Attribution 4.0 International License (http://creativecommons.org/licenses/by/4.0/), which permits unrestricted use, distribution, and reproduction in any medium, provided you give appropriate credit to the original author(s) and the source, provide a link to the Creative Commons license, and indicate if changes were made.

\section{References}

Allers MA, Hoeben C (2010) Besparingsmogelijkheden in het waterbeheer. COELO, Centrum voor Onderzoek van de Economie van de Lagere Overheden, Groningen

Anonymous (1839) Beschouwing van de dijkbesturen en hoogheemraadschappen in derzelven oorsprong, ontwikkeling en voortduring. Van der Meer \& Verbruggen, Rotterdam

Anonymous (1988) The Dutch water-boards, 2nd edn. Unie van Waterschappen, The Hague

Antonisse R (1980) Waterschapswerk; eb en vloed op de Beverlanden. Pitmandruk bv, Goes

Boer PJH (1963) Het tweede keerpunt. In: Het stroomgebied van de Dommel 1863-1963. Waterschap 'Het stroomgebied van de Dommel', Boxtel, pp 101-124

Boin A, Pt Hart, McConnell A (2009) Crisis exploitation: political and policy impacts of framing contests. J. Eur Public Policy 16(1):81-106

Boogers M, Tops P (2000) Waterschapsverkiezingen : over democratie en het bestaansrecht van waterschappen. Bestuurswetenschappen 4:293-295

Commissie Gemeenten-Waterschappen (1955) Rapport Commissie Gemeenten-Waterschappen. Vereniging van Nederlandse Gemeenten

Commissie Togtema (1999) Waterschapsbelastingen in de 21e eeuw. Eindrapport van de Commissie onderzoek financiering. Unie van Waterschappen, Den Haag

Commissie Waterschapsbestel (1967) Het waterschapsbestel. Wiardi Beckman Stichting, Amsterdam

Commissie waterschapsbestuur (1979) Het bestuur van get waterschap. Unie van Waterschappen

Deltacommissie (1961) Rapport Deltacommissie D1. 1: Eindverslag en interimadviezen. Staatsdrukkerij- en Uitgeverijbedrijf 's-Gravenhage

Denktank (1996) Water centraal; Waterbeheer in de volgende eeuw. Unie van Waterschappen, Den Haag

Donker H (1996) Water tussen Regge en Dinkel; waterschapszorg in Twente tussen 1934-1984. Waterschap Regge en Dinkel, Almelo

Donner TG (1935) Rapport omtrent de juridische vormgeving aan een centraal lichaam, hetwelk de zuivering van het afvalwater in het stroomgebied van de Regge zal hebben te bewerkstelligen op den voet als aangegeven in het rapport der Regge-Commissie. In: Studie-Commissie Ter Nadere Bestudeering van de Opheffing der Vervuiling van de Wateren In Het Stroomgebied van de Regge (ed) 
Rapport betreffende den arbeid van de studie-commissie ter nadere bestudeering van de opheffing der vervuiling van de wateren in het stroomgebied van de Regge. Almelo

De Vries Azn. Gd (1876) Het dijks- en molenbestuur in Holland's Noorderkwartier onder de grafelijke regeering en gedurende de Republiek Verhandelingen der Koninklijke Akademie van Wetenschappen. Afdeeling Letterkunde, dl. 10. Van der Post, Amsterdam

Gerritsen H (2005) What happened in 1953? The big flood in the Netherlands in retrospect. Philos Trans R Soc A 363(1831):1271-1291. doi:10.1098/rsta.2005.1568

Giebels L (1992) De zaak van de abandonnerende polder en de afschaffing van de waterschapsrechtspraak in 1841. Tijdschrift voor Rechtsgeschiedenis XL:449-470

Glim CMS, Slooijer J, De Bakker R, Tjalma H, Smallenbroek AJH, Ruiter C (2009) Samen naar beter; Evaluatie landelijke waterschapsverkiezingen 2008. BMC Onderzoek, Den Haag

Havekes H (2008) Functioneel decentraal waterbestuur: borging, bescherming en beweging; De institutionele omwenteling van het waterschap in de afgelopen vijftig jaar. SDU Uitgevers, Den Haag

Havekes H, Hofstra M (2014) Interview with Aziza Akhmouch, head of OECD water governance programme and project officer for the OECD-rapport 'Water governance in the Netherlands: fit for the future?'. Water Gov 2:10-15

Henderikx PA (2001) Land, water en bewoning: Waterstaats- en nederzettingsgeschiedenis in de Zeeuwse en Hollandse delta in de Middeleeuwen. Amsterdamse Historische Reeks, Grote serie deel 26. Verloren, Hilversum

Hoeben C (2011) Achtergrond waterschapsbestuurders en verdeling belastingopbrengsten. Weekblad fiscaal recht 6909:766-774

Hordijk LW (1983) Inventaris van de archieven van de polder Binnenland en Ziedewij. Waterschap IJsselmonde, Brielle

Huisman P (2002) How the Netherlands finance public water management. European Water Management Online

IJff J (1993) Omwentelingen in het waterschapsbestel 1968 - 1993. In: Raadschelders JCN, Toonen TAJ (eds) Waterschappen in Nederland : een bestuurskundige verkenning van de institutionele ontwikkeling. Verloren, Hilversum, pp 13-29

IJff J (1995) De bestuurlijke organisatie van het waterkwaliteitsbeheer. In: Van den Berge AP, Groen K, Havekes HJM, Hofstra MA, Teulings JHA (eds) Bestrijding van de watervervuiling; vijfentwintig jaar WVO. Unie van Waterschappen, Den Haag, pp 27-42

Jansen JH (1995) De bestrijding van de waterverontreiniging tot 1970. In: Van den Berge AP, Groen K, Havekes HJM, Hofstra MA, Teulings JHA (eds) Bestrijding van de watervervuiling; vijfentwintig jaar WVO. Unie van Waterschappen, Den Haag, pp 19-25

Josephus Jitta AC (1936) De corporatieve staatsgedachte in Nederland. Van Loghum Slaterus, Arnhem

Katsburg PRA (1996) De verkiezing verkozen. Het Waterschap 81(4):122-128

Kienhuis JHM (1993) De renovatie van het Nederlandse waterschapsbestel. In: Kienhuis JHM, Westerwoudt TW, Van de Wal JT (eds) Het waterschap van oud naar nieuw. Hoogheemraadschap van Delfland, Delft, pp 7-43

Kooiman D (1928-1932) Waterstaatwetgeving, vol 1-3. Samson, Alphen aan den Rijn

Lambooij H, Aten D (2002) "De held sterft niet"; Waterschapsconcentratie in Noord-Holland, 1916-2003. Uitwaterende Sluizen, Edam

Lazaroms R, Poos D (2004) The Dutch water board model. J Water Law 15(3-4):137-140

Maas WJM (1963) De Dijkwet van 1810; een algemene bijdragenwet in de Franse tijd. Nijgh \& Van Ditmar, Rotterdam/'s-Gravenhage

Mansholt (1941) Beschouwingen over een onderzoek naar de waterschapslasten in Nederland. Algemeene Landsdrukkerij 's, Gravenhage

Meijerink S (2010) Het arrangement voor regionaal waterbeheer en de toekomst van de waterschapsverkiezingen. Ministerie van Verkeer en Waterstaat, Den Haag

Ministerie van Verkeer en Waterstaat (1952) Lijst van waterschappen met hun adressen, provincie-gewijs gerangschikt. Staatsdrukkerij,'s-Gravenhage

Mostert E (2006) Integrated water resources management in The Netherlands: how concepts function. J Contemp Water Res Educ 135(1):19-27. doi:10.1111/j.1936-704X.2006.mp135001003.X

Mostert E (2012) Water management on the Island of IJsselmonde 1000-1953; Polycentric governance, adaptation and petrification. Ecol Soc 17(3):12. doi:10.5751/ES-04956-170312

Mostert E (2015) Who should do what in environmental management?; Twelve principles for allocating responsibilities. Environ Sci Policy 45:123-131. doi:10.1016/j.envsci.2014.10.008

North DC (1990) Institutions, institutional change and economic performance. Cambridge University Press, Cambridge

OECD (2014) Water governance in the Netherlands: fit for the future? OECD Studies on Water. OECD Publishing, Paris. doi:10.1787/9789264102637-en 
Ormel D (1954) De bestuurlijke zijde van het beleid. Het Zuid-Hollandse waterschapsrecht. Samsom, Alphen aan den Rijn, pp 1946-1954

Ostrom E (1990) Governing the commons: the evolution of institutions for collective action. The Political economy of institutions and decisions. Cambridge University Press, Cambridge

Pauwels A (1937) De oorsprong van de Belgische polderwetgeving : de politiek van Frankrijk (1794-1814) ten aanzien van de polders : de wording van de organieke keizerlijke decreten van den 11 Januari en van den 28 December 1811. Vlaamsche rechtskundige Bibliotheek. De Sikkel, Antwerpen

Pierson P, Skocpol T (2002) Historical institutionalism in contemporary political science. Polit Sci 3:693-721

Polak CHF (1954) Waterschapsrecht in beweging. In: Het Zuid-Hollandse waterschapsrecht, 1946-1954. Samsom, Alphen aan den Rijn

Provincie Noord-Holland (2004) Bewust omgaan met Water; 13 aansprekende interviews over maatschappelijke ontwikkelingen en water. Noord-Holland, Haarlem

Raad voor de financiële verhoudingen (2005) De prijs van water. Wie betaalt de rekening?, Rfv-Jaarrapport 2005. Den Haag

Raadschelders JCN, Toonen TAJ (1993) Theorie, casus en perspectief voor onderzoek. In: Raadschelders JCN, Toonen TAJ (eds) Waterschappen in Nederland : een bestuurskundige verkenning van de institutionele ontwikkeling. Verloren, Hilversum, pp 179-190

Roeffen HJM (1963) De waterstaat in het stroomgebied sinds 1800 en flitsen uit de geschiedenis van het waterschap. In: Het stroomgebied van de Dommel 1863-1963. Waterschap 'Het stroomgebied van de Dommel', Boxtel, pp 36-100

Schilthuis GJC (1960) Waterschapsrecht, 2e edn. Samsom, Alphen aan den Rijn

Schorer JA (1897) De geschiedenis der calamiteuse polders in Zeeland tot het reglement van 20 Januari 1791. Ijdo, Leiden

Slager K (2003) De ramp : een reconstructie van de watersnood van 1953, 2nd rev. edn. Atlas, Amsterdam

Smit R (2004) Waterschappen houden waterbeheersing onnodig duur: Geld als water. Forum 15-7-2004

Soens T (2009) De spade in de dijk? Waterbeheer en rurale samenleving in de Vlaamse kustvlakte. Academia Press, Gent

Studie-Commissie Ter Nadere Bestudeering van de Opheffing der Vervuiling van de Wateren In Het Stroomgebied van de Regge (1935) Rapport betreffende den arbeid van de studie-commissie ter nadere bestudeering van de opheffing der vervuiling van de wateren in het stroomgebied van de Regge. Almelo

Studiecommissie Waterschappen (1974) Het Waterschap en zijn Toekomst. Staatsuitgeverij,'s-Gravenhage

Theunissen G (2012) Water als rode draad : een onderzoek naar het politiek gehalte van de besluitvorming in het bestuur van de waterschappen. Centrum voor Lokaal Bestuur, Amsterdam

Toonen TAJ, Glim MCS (2000) Een bestuursschouw van het waterschap, studie in opdracht van het Interprovinciaal Overleg (IPO). Ernst \& Young Consulting, Utrecht

Toonen TAJ, Dijkstra GSA, Van de Meer F (2006) Modernization and reform of Dutch waterboards: resilience or change? J Inst Econ 2(2):181-201

Van de Berg JT (1982) Waterschap en functionele decentralisatie. Samsom Uitgeverij, Alphen aan den Rijn

Van de Ven GP (ed) (2004) Man-made lowlands history of water management and land reclamation in the Netherlands, 4th edn. Matrijs, Utrecht

Van den Noort J (2009) Langs de rand van het zand. Waterschap Brabantse Delta, Breda

Van der Flier G (ed) (1946) Het Hoogheemraadschap Noordhollands Noorderkwartier 1920-1945. Meijer, Wormerveer

Van der Ham W (1999) Heersen en beheersen: Rijkswaterstaat in de twintigste eeuw. Europese Bibliotheek, Zaltbommel

Van der Ham W, Jacobs I (eds) (2004) Hoge dijken, diepe gronden. Land en water tussen Rotterdam en Gouda: een geschiedenis van Schieland. Matrijs, Utrecht

Van Doorn JAA (1989) Schets van de Nederlandse politieke traditie. In: De Beus BJW, Van Doorn JAA, Lehning P (eds) De ideologische driehoek; Nederlandse politiek in historisch perspectief. Boom, Amsterdam/Meppel, pp 11-60

Van Lohuizen K (2006) Afvalwaterzuivering in Nederland; Van beerput tot oxidatiesloot. RWS RIZA rapport 2006.011. RWS-RIZA, Lelystad

Werkgroep IBO Bekostiging Waterbeheer (2004) IBO Bekostiging Waterbeheer. www.minfin.nl/binaries/ minfin/assets/pdf/dossiers/diversen/beleidsonderzoeken/ibo-s-2002/bekostiging-waterbeheer-rapport.pdf

Werkgroep Waterschapsfinanciën (1967) Rapport Werkgroep Waterschapsfinanciën. Staatsdrukkerij, 'sGravenhage

Yzerman MJ (1934) Waterschap “De Regge”. N.V. de Erven J.J Tijl, Zwolle 
Erik Mostert is an assistant professor at the Water Management group of the Delft University of Technology. Trained as a lawyer and social scientist, his research focuses on institutional development and collaboration processes in water management, often using a long-term perspective. His work has concentrated on the European Union and the Netherlands. 